\title{
Care as a commitment of all: a study in a rural settlement
}

\author{
Simone Wunsch ${ }^{\mathrm{a}}$ \\ Maria de Lourdes Denardin Budób \\ Nara Marilene Oliveira Girardon-Perlinic \\ Raquel Potter Garciad \\ Stefanie Griebeler Oliveirae
}

DOl: $\quad$ http://dx.doi.org/10.1590/19831447.2014.04.28526

\section{ABSTRACT}

This study aims to understand the perceptions of care of families living in a rural settlement in the northwestern area of Rio Grande do Sul. It is an ethnographical based qualitative field research, which has used the Observation-Participation-Reflection Model for data collection, performed between February and March, 2011. The data analysis went through four steps: raw data collection and documentation, describers and indexes identification, contextual and current patterns analysis, and identification of research themes and relevant findings. The study has shown that, for the settlers who participated in the study, care is bound to their vision of world, meaning a commitment of everybody, under the collective and individual premise of improvement of their lives. It is concluded that Nursing needs to understand cultural behaviors in order to enable a congruent and holistic care.

Descriptors: Nursing, Culture. Nursing care. Rural settlements.

\section{RESUMO}

Este estudo objetiva conhecer as percepções de cuidado para as famílias residentes em um assentamento rural na região noroeste do Estado do Rio Grande do Sul. Trata-se de uma pesquisa de campo qualitativa de vertente etnográfica, que utilizou o guia habilitador Modelo Observação-Participação-Reflexão para coleta de dados, realizada no período de fevereiro a maio de 2011. A análise dos dados se deu em quatro fases sequenciais: coleta e documentação dos dados brutos; identificação dos descritores e indicadores; análise contextual e de padrões atuais; e identificação dos temas e dos achados relevantes da pesquisa. 0 estudo evidenciou que 0 cuidado, para os assentados, encontra-se vinculado à sua visão de mundo, significando um compromisso de todos sob a premissa coletiva e individual para melhorarem de vida. Conclui-se que a enfermagem necessita compreender os comportamentos culturais para possibilitar um cuidado holístico e congruente.

Descritores: Enfermagem. Cultura. Cuidados de enfermagem. Assentamentos rurais.

\section{RESUMEN}

Este estudio objetivó conocer las percepciones de cuidado para las familias residentes en un asentamiento rural en la región noroeste del Estado de Rio Grande do Sul. Se trata de una investigación de campo cualitativa de vertiente etnográfica, que utilizó la guía habilitadora Modelo Observación-Participación-Reflexión para recolección de datos, realizada en el período de febrero a mayo de 2011. El análisis de los datos se dio cuatro fases secuenciales: recolección y documentación de los datos brutos, identificación de descriptores e indicadores, análisis contextual y de estándares actuales e identificación de los temas y hallados relevantes de la investigación. El estudio evidenció que el cuidado, para los asentados, se encuentra vinculado a su visión de mundo, significando un compromiso de todos bajo la premisa colectiva e individual para mejorar de vida. Se concluye que la enfermería necesita comprender los comportamientos culturales para posibilitar un cuidado holístico y congruente.

Descriptores: Enfermería. Cultura. Cuidados de enfermería. Asentamientos rurales 


\section{DINTRODUCTION}

Rural settlements are a result of governmental policies focused on social equity, through a more suitable land distribution for productive use. They are formed by families, who previously lived in camps, that prioritize the collectivity, permeated by specific experiences, values, principles and meanings $s^{(1)}$.

After their installation, the rural settlements began to be regarded as rural communities and/or populations, often located in areas geographically distant from urban centers. The families lived in these spaces, and also constructed there their social paths ${ }^{(2)}$, established their interactional dynamics, that distinguished the rural environment from other environments.

Care practices in the rural environment have some peculiarities. The rural families settled perceive and practice care through objective and subjective aspects, which refer to their relationships with the Movement of Landless Rural Workers $(M S T)^{(3)}$. Besides, there is a reconstruction of the worldview, as the movement provides the families with empowerment, inclusion, discernment and the understanding that the right to land, health and construction of autonomy and social inclusion is only possible when all the people organize themselves ${ }^{(4)}$.

Thus, the care for families in rural settlements is a cultural care, since the social and cultural structure and worldview affect the health care practices. Cultural care comprises the values, beliefs and patterns of learned and transmitted ways of life, which enable individuals or groups to maintain their well-being and health, recognizing their worth as human beings, or helping them cope with disease, disabilities or death ${ }^{(5)}$.

For the settled families, cultural care is manifested and standardized in expressions, actions, lifestyles and meanings, being based on the perception of the world, on the environmental context, history, beliefs and values. Therefore, in nursing, an activity essentially concerned with care, the professionals should be aware of the different cultural behaviors of the families, to be able to provide a congruent care ${ }^{(5)}$.

In the daily practice in health services in a city with several rural settlements, it can be seen that the population in these settlements is excluded from the local health care policies. Because of their peculiarities, it is a vulnerable population that needs to be understood in their individuality, to be cared. Therefore, in order to expand the existing knowledge on this population group, we ask: How do the settled families perceive care? By posing this question, we aimed, in this study, to know how families living in a rural settlement, in the northwestern region of the State of Rio Grande do Sul (RS) perceive care practices.

\section{$\square$ METHOD}

This is a qualitative research of ethnographic nature. Ethnography is a study that allows for interaction and exchange between researcher and research subjects, with emphasis on everyday life and subjective aspects, so that a consistent description is obtained. ${ }^{(5,7)}$ In nursing, ethno-nursing was developed as a research method to assist nurses to study, document and analyze the local perspective of the beliefs, values and practices of care perceived and known by a particular culture through their direct experience. ${ }^{(5)}$

The scenario where the study was conducted was a rural settlement in the northwestern region of the State of Rio Grande do Sul, consisting of 53 plots of land, of which 48 were occupied during the study period. The families settled in that location and the participants of the study came from different camps, and the total geographical area of the settlement was 829.55 hectares.

The following inclusion criteria were considered for participation in the study: attendance by a family member of a meeting during which the research was presented; members should be over 18 years old; and be living in the settlement for at least two years. The time frame of two years was stipulated because it was believed that this was the time required for the families to be integrated in the sociocultural context that permeates the community.

The Model Observation-Participation-Reflection (OPR) ${ }^{(5)}$ was used in data collection, which is a guide recommended to explain cultural care ${ }^{(5)}$. Semistructured interviews were also used. The sources of information that involve ethno-nursing are called key informants and general informants ${ }^{(5)}$. The key informants were purposefully selected and consisted of the subjects with greater communication skills in each family, and the other members of the families were considered general informants.

The data were recorded in a field diary, a "notebook where researchers record their daily observations and which are not the object of any type of interview ${ }^{\prime \prime(8)}$. The record of the observations was preceded by an identification consisting in the date, time, place and situations observed during that period.

Four families, delimited by data saturation, were monitored in the study. "Empirical saturation" refers to the situation where the researcher believes that the latest documents, interviews or observations no longer bring new or different information to justify carrying on gathering more 
empirical data ${ }^{(9: 198)}$. The data were collected from February to May 2011.

Data analysis was based on the guide to the steps of data analysis of ethno-nursing ${ }^{(5)}$, which proposes four sequential phases. Step I refers to the collection and documentation of raw data; step II concerns the identification of descriptors and indicators; step III, the contextual analysis and current standards and step IV, the identification of issues and relevant research findings.

The study was conducted according the requirements of Resolution 196/96 of the National Council of Health, with the project approved by the Ethics Committee under the CAAE (Certificate of Submission for Ethical Review), no 0356.0.243.000-10.

The confidentiality of the families participating in the study was preserved with the use of letter " $\mathrm{S}$ " (subject) and "F" (family), followed by the number that indicates the order of the interviews. For example: SF01; SF02; and so on.

\section{QRESULTS AND DISCUSSION}

The theme "Care to improve life - a commitment of all" emerged during the time spent with the families, for collection and data analysis. This theme consists of two categories: "our fight continues": a commitment of all the families to improving living conditions.

The families perceive care, in their culture, as a collective and individual commitment to improve their living conditions. The collective aspect comprises the organization of all the members regarding commitment, obligation, mobilization and claim. The individual aspect involved commitment to the house and the surroundings of the plot, expressed as routine, cleanliness, assistance and production.

\section{"Our fight continues": a commitment of all the families to improve living conditions}

Care as a commitment of all the members of the rural settlement was introduced and culturally assimilated by the families during their experience in the camps. This is a strategy for action, a form of cooperation, unity and political organization capacity of the families to achieve an objective.

In the settlement, the families sought to maintain this organization, characterized by collective participation in the dairy cooperative of the members of the settlement, in the movement to ensure drinking water supply for the families and in the demand for paved roads. Care as a commitment of all individuals in the settlement involved commitment and obligation, demonstrated in the participation of the members in meetings and decisions, according to a note of the field diary.

The families in the rural settlements founded a dairy cooperative, aiming to improve their living conditions. However, not all families have joined the cooperative, and not all the partner families had an active participation in the meetings. The families organized in cooperatives usually convene meetings to make collective decisions on several issues, training activities, technical guiding, discuss the price paid for a liter of milk, among others. The fiscal council of the cooperative, also formed by the families, meets separately to examine the accounts of the cooperative, and in case of disagreement or inaccuracies, a new meeting of the cooperative members is convened, so that a collective decision is made (fragment of the field diary 06/02;07/02/2011)

The rural settlement has an organizational structure aimed at self-management and demands the commitment of the families. This is a form of social or participatory democracy where the involved families, are more than mere beneficiaries of a given system, and become protagonists of their own lives and of the possibilities to improve their social conditions, given their autonomy to make their own decisions.

The conditions and the daily life of the members of the rural settlement are very peculiar, because of several factors, with emphasis to their daily experience with decisions and collective actions. These experiences can affect the health conditions of the families, since they result from a historical and also collective construction process of respect to the decisions made by the individuals committed with the construction of their own well-being ${ }^{(1)}$.

Still, one must consider that the organization of productive strategies satisfies the interpretations and representations of the social events experienced and marked by the cultural references of the families ${ }^{(2)}$. The sociocultural differences and the different conceptions about care as a commitment may justify the fact that not all families were partners of the dairy coooperative of the settlement.

According to the families, care as a collective commitment was also observed in the mobilization and demand for drinking water supply, as reported by those members when they claimed that health is associated to water quality.

"[...]" we have been living in the settlement for four years, and now the city hall is providing the hoses for water"[...]" We mobilized ourselves, organized ourselves and de- 
manded this, because we needed it most "[...]". Last year, during summer, some people became sick here "[...]" the people in the settlement. The doctor said that this condition was related to something in the water. Only those who drank water supplied by the community were not affected. (SF 04)

Water of poor quality or untreated exposes the families to several risks, which can affect the life and health of everyone, either by direct or indirect ingestion, in food preparation, in personal hygiene, in agriculture or in the environment. The pathogenic bacteria found in water or food handled with water of poor quality are important sources of morbimortality in our country, accounting for enteritis, infant diarrhea, endemic and epidemic diseases that can result in deaths ${ }^{(10)}$.

The rural areas often do not count on drinking water supply or else water supply involves the use of boxes for collection or artesian wells. Because of these inadequate conditions of water supply the rural families may become vulnerable and susceptible to many diseases ${ }^{(11)}$.

Also, for these families, care as a commitment of all the members, is provided through diverse strategies, that consider cultural aspects related to their fights, especially land reform. These fights include demands for a better road infrastructure (e.g. paved roads) to facilitate access to services, markets, etc, since, in their testimonies, the members of these rural settlements suggested that poor health care was associated to inadequate road and transport infrastructure:

When we arrived here we were told that the broads would be improved and that accesses would be provided to the house. These machines are here because we kept asking for them; it is our fight, but things are not all right and we will have problems soon. The National Institute for Colonization and Agrarian Reform (INCRA) has the responsibility of opening roads when an area that cannot be accessed because of lack of road infrastructure is occupied by a settlement. The city hall is responsible for maintaining the roads. "[...]" there has been pressure on the institute because of the organization of the Dairy Cooperative. (SF 03)

"[...]" some people still haul those buckets or cans, 50-liter milk containers, when it rains, to the paved road. There are also people who walk 1 or $2 \mathrm{~km}$ [carrying buckets on the back], which is harmful to health. Can you imagine this, every two or three days, people hauling around 200, 300, 400 liters of milk "[...]". (SF 04)
The poor conditions of public roads cause problems to the families, particularly in rainy days, as observed in the last excerpt. Poorly preserved roads may affect production (logistics) and make it difficult for the population to keep living in the settlement (lack of mobility infrastructure), as well as to access schools, health services, etc. So, these people are sometimes exposed to extreme situations to maintain their livelihood, working under unhealthy working conditions.

Geographical factors have impact on the opportunities of access to health services ${ }^{(12)}$, in many Brazilian states. The poor conditions of the rural environment cause access problems, especially in rainy days, both regarding the production flow and the access to health services, representing a potential risk to health and leading in isolation and economic losses that ultimately impact the quality of life of the families ${ }^{(11)}$. The families must rely on their physical strength to survive in rural areas, and, thus, nursing should help these families improve their skills to address problems and perform their activities in a healthier way ${ }^{(6)}$.

The implementation of rural settlements minimizes poverty, but does not contribute to reduce social differences or strengthen the autonomy of the families. The public policies involved in the process of land reform are fragmented and poorly coordinated, because they only mitigate social tensions, create an illusion of autonomy, and assign to the subjects, here represented by the families, the responsibility for their own care. Such attitudes further reduce the State's responsibility in solving social problems ${ }^{(13)}$.

\section{The house and the surroundings: a commitment of the family to improve living conditions}

Based on sociocultural differences, care as a commitment of all can be understood as the way in which the families and their members developed their housekeeping activities and also cared for the external environment. Therefore, care is a mutual commitment between the members of the family, a duty, as shown in the statements below:

We all keep [the house]. Everybody helps. When there is nothing to do outside the house [surroundings] she [daughter-in-law] helps me [keeping the house] (SF01)

"[...]" at home, everybody [all the residents in the house] participate "[...]"everybody helps when I have to go out. You see, when I get home, everything is ready [...] in the yard "[...]", we do what we can "[...]" (SF04) 
The places where the families of the rural settlement lived comprised the house and the spaces within the plot where some care practices were performed by the families in their daily routine. Housing is associated to the life history of these families when they join the MST and represents safety, comfort, quality of life and improvements to cope with the social inequalities experienced so far.

Since the first references to primary health care, in Alma Ata, in the Conference on Health Promotion, in Ottawa, housing has been considered a precondition for health ${ }^{(14)}$. One indirect benefit of land ownership and of the control of production means, which can be conceived as a solution for part of the problems faced by several families. Housing becomes the organizing element, a reference to people's lives ${ }^{(15)}$, thus, to the families, rooting them in the settlement, restoring their self-esteem.

Care as a commitment of all involved following a daily routine to organize the activities performed in the plot, as shown in the subsequent statements.

We all [the residents] keep the house "[...]" they [refers to the other residents in the house] they take care of the animals outside the home, deal with fences, with pasture, with the cattle, with the calves, and I keep the house. They [all the residents] have their room, we have ours, we keep our rooms neat and tidy in the morning "[...]" everybody helps with the yard, the kitchen garden "[...]". (SF01)

In our home almost everyone helps, but we have a routine to follow: I wake up, light the fire, heat the water, send the children to school, then the adults come from outside, then I make coffee"[...]" clean the house... (SF04)

The families identified the daily tasks as care practices because they intended to organize their ways of life. These habits are based on the social context where these families are inserted, guided by cultural aspects ${ }^{(16)}$.

The families in the rural communities have intense and permanent routines that must be observed every day, and these daily work habits established by the residents ensure that they have the essential for survival, allowing the growth of the family.

The house needs constant cleaning [silence] we need to plant a kitchen garden, cut flowers to embellish the house. We have to keep the court yard clean, tidy, remove the weeds, so it does not turn into a swamp. (SF02)

We do our maximum. We do the laundry in alternate days to prevent diseases. We also clean the floor mats, the tow- els. The dishes are washed every day "[...]", we have to be careful. Clean the bowl, the pump, using hot water, carefully, because of the bacteria. If we are not careful we can get sick... We have no support. (SF01)

In their concern for domestic activities, which include organizing, embellishing the house, removing the weeds from the surroundings, do not leave clothes scattered around the home, the families showed that care is a commitment to them. These care practices aimed to prevent the emergence of diseases, and were manifested in care for the health of the member of the families, through health prevention actions.

The statement of Alma-Ata and the Ottawa charter indicate that health is associated to the socioeconomic processes $^{(14,17)}$. The Ottawa charter emphasizes that health should be understood as a lifelong resource, and proposes the essential conditions for its development, such as peace, housing, education, food income, stable ecosystem, sustainable resources, social justice, equity. In the Charter it is also stated that, among other factors, we should promote positive changes in our environment to reach a physical, mental and social well-being ${ }^{(14)}$.

However, the rural population in the settlement had not adequate health care coverage ${ }^{(18)}$, which led the families to attempt to obtain these services, in their own way.

Thus, the cultural habits of care, demonstrated in the personal behavior within the social context of this group, can be considered preventive actions aimed to prevent the onset of diseases ${ }^{(19)}$.

Another evidence of care as a commitment is related to the concern of the families and their members to make it clear that they worked in the land that they obtained under the land reform program.

We have to produce, to work, so that no one thinks we are idle "[...]". (SFO1)

I love to see everything tidy. People are always coming around. I am always sweeping the floor, removing the weeds"[...]" The boys also help. (SF04)

The families stressed that they were not idle, since their daily routine involved performing constant tasks.. They also stressed that the land they acquired under the land reform program has fulfilled its social function, that is, the families were cultivating the soil and producing food. . This concern stems from the process of stigmatization of families in rural settlements and on the historiography of the agrarian problem in Brazil, which reflect the process of formation of society. 
For the families, the land is a place to call their own, where it is possible to establish a home, take care of the family and children. The land conquered by work, and by fighting has a symbolic and social value, constituting a "field of opportunities"(2:383). However, the predominant social forces, conservative and connected to the employers, advocate the sacred and inviolable right to property, arguing that that land should belong to those who are able to make it productive, and that the "agrarian reform, which led to rural settlements, would disrupt production"(20:131). Aware of this discrimination the families established care as a commitment to maintain the productivity of the plot of land. The proliferation of stigmas is related to the social structure of the collectivity, and the social factors impact health behaviors ${ }^{(16)}$.

Care as a commitment of all, either collectively of individually considered, based on a new worldview, which allows that the families improve their social conditions., is a standardized cultural practice. In their provision of care to these families, nursing, needs to establish a close and attentive relationship. Get to know these families in their context, with their worldviews and care practices, may provide a care more suitable to this sociocultural context.

\section{GINAL CONSIDERATIONS}

Our findings demonstrate that the care practices of families in the rural settlements are based on a world view identified with a commitment of all, which they acquired during their experience in the camp.

In the camp, the families were encouraged to reflect on the influence of social factors on health and to (re) construct their attitudes toward life, which reflects in the care practices, with a delignification of worldview and care.

Care as a commitment indicates that the families in the rural settlement conceived the plot of land and their territory as the opportunity to redefine their lives, despite all the difficulties and prejudices. Care as a commitment involved the work of the organization, cleanliness and assistance in house tasks as implicit components of intra-family relationships in the house, to prevent sickness.

In nursing, an activity essentially concerned with care, the professionals should be aware of the different cultural behaviors of the families, to be able to provide a congruent and holistic care.

This new approach to life focused on the collective commitment permeates and reflects the daily behavior of the families regarding the means of social and economic survival and quality of life, because these families are now attentive to the social context and the complexity of their environment, aiming to improve their lives..

\section{REFERENCES}

1. Cavalcante IMS, Nogueira LMV. Práticas sociais e coletivas para a saúde no assentamento Mártires de Abril na ilha de Mosqueiro. Belém, Pará. Esc. Anna Nery Rev Enferm. 2008;12(3):492-9.

2. Piccin MB, Moreira RJ. Habitus e agricultores-assentados: um estudo de caso no assentamento Ceres, RS. Estud Soc Agric [Internet]. 2009 [citado 04 fev 2012];17(2):379-421. Disponível em: http://r1.ufrrj.br/esa/V2/ojs/index.php/ esa/article/view/317/313

3. Wunsch S. Cuidado em saúde nas famílias em assentamento rural: um olhar da enfermagem [dissertação] Santa Maria: Universidade Federal de Santa Maria; 2011.

4. Silveira SMP. 0 sujeito sem terra. Em Tese [Internet]. 2008 [citado 27 mar 2011];5(1):49-73. Disponível em: https://periodicos.ufsc.br/index.php/emtese/article/view/1806-5023.2008v5n1p49/12342

5. Leininger M, McFarland, MR, editors. Culture care diversity and universality: a worldwide nursing theory. 2nd ed. Sudbury: Jones and Bartlett; 2006.

6. Zillmer JGV, Schwartz E, Ceolin T, Heck RM. A família rural na contemporaneidade: um desafio para a enfermagem. Rev Enferm UFPE on line. 2009;3(2):74954.

7. Flores GC, Borges ZN, Budó MLD, Mattioni FC. Cuidado intergeracional com 0 idoso: autonomia do idoso e presença do cuidador. Rev Gaúcha Enferm. 2010;31(3):467-74.

8. Minayo, CS. O Desafio do conhecimento: pesquisa qualitativa em saúde. 11. ed. São Paulo HUCITEC; 2008. 406p.

9. Pires PA. Amostragem e pesquisa qualitativa: ensaio teórico e metodológico. In: Poupart J, Deslauriers JP, Groulx LH, Lapemère A, Mayer R, Pires AP, organizadores. A pesquisa qualitativa: enfoques epistemológicos e metodológicos. Petrópolis, RJ: Vozes, 2008. p. 154-211.

10. Fundação Nacional de Saúde (BR). Manual de saneamento. 4 ed. rev. Brasília; 2006. 408p.

11. Leite S, Heredia B, Medeiros L, Palmeira M, Cintrão R. Impacto dos assentamentos: um estudo sobre o meio rural brasileiro. São Paulo: Ed. UNESP; 2004.

12. Eisenhauer CM, Hunter JL, Pullen CH. Deep roots support new branches: the impact of dynamic, cross-generational rural culture on older women's response to formal health care. Online Journal of Rural Nursing and Health Care [Internet]. 2010 [citado 03 nov 2011];10(1):48-59. Disponível em: http://rnojournal.binghamton.edu/index.php/RNO/article/download/73/57

13. Scopinho RA. Condições de vida e saúde do trabalhador em assentamento rural. Ciênc Saúde Coletiva [Internet]. 2010 [citado 25 mai 2011];15(Supl 1):1575-84. Disponível em: http://www.scielo.br/pdf/csc/v15s1/069.pdf

14. Carta de Ottawa. Primeira Conferência Internacional sobre Promoção da Saúde [Internet]. Ottawa; 1986[citado 22 ago 2011]. Disponível em: http://bvsms. saude.gov.br/bvs/publicacoes/carta_ottawa.pdf

15. Ryan A, Mckenna $H$, Slevin 0 . Family caregiving and decisions about entry to care: a rural perspective. Ageing Soc. 2012;32(1):1-18.

16. Riquinho DL, Gerhardt TE. Necessidades, práticas e apoio social: dimensões subjetivas dos determinantes sociais de saúde. RECIIS Rev Eletr Com Inf Inov Saúde [Internet]. 2008[citado 04 fev 2012];2(2):69-73. Disponível em: http://www. reciis.cict.fiocruz.br/index.php/reciis/article/view/124/131 
17. Declaração de Alma-Ata. Conferência Internacional sobre Cuidados Primários de Saúde [Internet]. 1978 [citado 18 ago 2011]. Disponível em: http://cmdss2011.org/site/wp-content/uploads/2011/07/Declaração-Alma-Ata.pdf

18. Victora CG, Barreto LM, Leal MC, Monteiro CA, Schmidt MI, Paim J, et al. Condições de saúde e inovações nas políticas e saúde no Brasil: o caminho a percorrer. The Lancet Saúde no Brasil. 2011[citado 07 nov 2011];90-102.
Disponível em: http://download.thelancet.com/flatcontentassets/pdfs/brazil/brazilpor6.pdf

19. Czeresnia D. Promoção a saúde: conceitos, reflexões, tendência. Rio de Janeiro: Ed. Fiocruz; 2003. 176p.

20. Medeiros LS de. A luta por terra no Brasil e o Movimento dos Trabalhadores Rurais sem Terra. 2009 [citado 21 fev 2011]. Disponível em: http://www.planalto. gov.br/gsi/saei/palestra/cgeevf.pdf.
Author's address:

Simone Wunsch

Rua Julio de Castilhos, 3113, Centro

97800-000, São Luiz Gonzaga, RS

E-mail: simone.wunsch@gmail.com
Received: 14.05.2012

Approved: 25.11.2014 